\title{
COMPETITIVENESS OF COMPANIES EXPRESSED BY THE RELATIONSHIP BETWEEN THE STRUCTURE OF FUNDING SOURCES AND THE LIQUIDITY OF COMPANIES IN THE VISEGRAD GROUP COUNTRIES
}

\author{
[Konkurenceschopnost podniků vyjádřená vztahem mezi strukturou zdrojů \\ financování a likviditou podniků v zemích Visegradské čtyřky] \\ Markéta Šeligová ${ }^{1}$ \\ ${ }^{1}$ Slezská univerzita, Obchodně podnikatelská fakulta, Univerzitní nám. 1934/3,733 40 Karviná \\ Email:seligova@opf.slu.cz
}

\begin{abstract}
The aim of this paper is to determine the effect of the structure of funding sources on liquidity of companies in energy sector in the Visegrad group from 2006 to 2015. With the purpose to fulfill the aim, we examine existence and character of relationship between the structure of funding sources (debt equity ratio, equity ratio, return on equity, return on assets and fixed assets to total assets) and liquidity of the companies in energy sector in Visegrad group. The existence of relationship between the structure of funding sources and liquidity of companies is tested by correlation analysis and generalized method of moments (GMM). The results show that there is the negative impact of return on assets on liquidity of companies in the Visegrad group. The liquidity of companies was positively influenced by the return on equity and negatively influenced by debt equity ratio in energy sector in the Visegrad group.
\end{abstract}

Keywords: correlation, debt equity ratio, equity ratio, fixed assets, liquidity of companies, GMM, return on ekvity.

JEL classification: G32

Received: 18.10.2018; Reviewed: 28.10.2018; 29.10.2018; Accepted: 19.6.2019

\section{Introduction}

The enormous development of the theoretical and empirical literature on corporate finance in recent years has brought a wealth of insights into how the capital structure is important for the value of the firm and for its investment decision-making. Equally important is the company's liquidity. Liquidity of company may be related and may be affected by its capital structure to a certain extent. According to Titman and Wessels (1988), the capital structure of items from which the company finances its assets through foreign resources and own resources. Based on economic theories, a companies should use a balanced combination of both equity and debt capital to finance its business activities.

Ghasemi and Razak (2016) believe that the dilemma between equity and debt capital is one of the most important managerial decisions. More equity increases the demands on external cash flow, which will consequently reduce the value of the company. Conversely, more debt capital increases costs and may exacerbate the financial distress that is associated with bankruptcy. These are also related to the conclusions of Lipson and Mortal (2009), who concluded that companies use less debt capital and prefer equity financing when they have a higher liquidity.

The aim of this paper is to determine the effect of the structure of funding sources on liquidity of companies in energy sector in the Visegrad group from 2006 to 2015. With the purpose to fulfill the aim, we examine existence and character of relationship between the structure of 
funding sources (debt equity ratio, equity ratio, return on equity, return on assets and fixed assets to total assets) and liquidity of the companies in energy sector in Visegrad group including the Czech Republic, the Slovak Republic, Poland and Hungary.

In order to achieve the goal, the following research questions will be identified and evaluated:

- What is the impact of own funding sources on the liquidity of companies in the the Visegrad group?

- What is the impact of debt funding sources on the liquidity of companies in the Visegrad group?

The first part of this article will include a literature review. The second part of this article will focused on methodology and data. The third part of this article will contain results. Last part of this article will conclude results and discussion.

\section{Literature review}

Williamson (1988), Schleifer and Vishny (1992), Anderson (2002) believe that more liquid companies are less costly to monitor and liquidate therefore higher liquidity growth leverage. On the contrary, De Jong et al. (2008), Lipson and Mortal (2009), Sarlija and Harc (2012) argue that more liquid companies are less indebted, because they could use the additional liquidity to internally finance their activities.

Anderson (2002) examined the relationships among the firm's financial structure, its choice of liquid asset holdings and growth on UK and Belgian companies. Using regression analysis he examined the factors determining liquid asset holdings and the link between firm liquidity and capital structure using the following variables: liquidity (dependent variable, sum of cash, bank balances, and investments in current assets di-vided by total assets) and independent variables such as cash flow (earnings before taxes and interest divided by total assets), long term debt, medium term debt, short term debt, $R \& D$ expenditures and market value to book value. The results revealed positive associations between leverage and liquid asset holding.

One of funding sources are depreciation that are related with fixed assets. For this reason, it is appropriate to examine the relationship between liquidity of companies and depreciation through fixed assets. Unfortunately, there is only minimum specific studies that focus on this relationship. For this reason, study of Mehar (2005) was selected to the literature review. He examined whether equity financing plays a central role in determination of the liquidity position of a companies in Pakistan. The relation between the equities and working capital has been observed. He analyzed relation be-tween liquid assets (dependent variable) and independent variables such as fixed as-sets at historical cost, net profit after tax and retained earnings. There was found that liquidity is positively correlated with fixed assets. An increase in the fixed assets will lead to the increase in depreciation expenditure, so, availability of the funds will be in-creased without a decline in the cash balance. He found that depreciation fund has been classified as a source of liquidity. The long-term debt may deteriorate the liquidity position of a firm. The results show that profit and liquidity have significant positive relation where relation between liquidity and retained earnings was found as negative.

Ganesan (2007), through correlation analysis and regression analysis, examined the relationship between profitability, operating capital and liquidity in telecommunication equipment. The findings of the study showed a negative impact between liquidity and 
profitability. Correlation analysis as a suitable method for completing the regression analysis was used, for example, in Franzoni, Nowak and Phalippou (2010), dealing with the relationship between equity and liquidity of US and European companies in particular.

Shah (2012) examined relationship between profitability and liquidity trade off through the application of working capital analysis in India. This study undertakes the identification of the key variables that influence the working capital management and its impact on profitability and liquidity of pharmaceuticals manufacturers. He examined the relationship between liquidity (dependent variable, including current ratio) and independent variables (components of working capital) such as gross operating cycle period and quick ratio. It has been found that there is a positive relationship between liquidity and variables such as quick ratio and gross operating cycle period. He examined the relationship between liquidity (current ratio) and profitability (earnings be-fore depreciation, interest, and tax as a percentage of assets). It has been found that there is a negative relationship between liquidity and profitability.

Šarlija and Harc (2012) investigated the impact of liquidity on the capital structure of Croatian firms. Pearson correlation coefficient was applied to the test on the relationship between liquidity ratios and debt ratios, the share of retained earnings to capital and liquidity ratios and the relationship between the structure of current assets and leverage. The results showed the existence of a statistically significant negative correlations between liquidity ratios and leverage ratios. The results showed that there are statistically significant correlations between leverage ratios and the structure of current assets. The relationship between liquidity ratios and the short-term leverage is stronger and negative than positive relationship between liquidity ratios and the long-term leverage. The more liquid assets firms have, the less they are leveraged. Long-term leveraged firms are more liquid. Increasing inventory levels leads to an increase in leverage. Furthermore, increasing the cash in current assets leads to a reduction in the short-term and the long-term leverage.

Trippner (2013) analyzed the relationship between liquidity (cash ratio, current ratio and quick ratio) and profitability (return on assets - ROA, return on equity - ROE) in the Polish companies from 2002 to 2012 . Using correlation analysis it has been found that there is a positive and negative relation between liquidity and ROA and ROE.

Miloś (2015) analyzed the determinants of capital structure of the Romanian companies using panel data. He used variables including ratio between total debt and total liabilities, profitability (return on assets), liquidity (ratio between current assets and current liabilities), tangibility (ratio of tangible assets divided by the total assets) and size (natural logarithm of total sales). The results show that there is a negative connection between liquidity and leverage. The results suggest that less liquid companies obtain the necessary capital by borrowing. Companies often prefer and use a short-term loans when there is a lack of liquidity.

Růčková (2015) analyzed the impact of liquidity and profitability on use of deb finance sources of companies in manufacturing industry in V4 countries. She examined the relationship between using debt sources (debt/equity ratio) and liquidity. The study results showed a positive relationship between liquidity and using debt sources in the Czech Republic. It can be stated that the increasing liquidity of companies is also increasing the using debt sources. 


\section{Materials and Methodology}

Given that the article focuses on liquidity of companies in the Czech Republic, the Slovak Republic and Poland, it is appropriate to mention that various sectors of the economy are involved to varying degrees in the consumption and production of the national economy. The sectors such as mining and quarrying, manufacturing, construction, service sector and energy sector represent the largest proportion of the performance of the Czech, Slovak economy and Polish economy. For this reason, the article focuses on determine the relationship between the funding sources and liquidity of the companies in energy sector.

All financial date are taken from Amadeus database. This database includes data from the annual reports of individual companies in energy sector the Czech Republic and Slovak Republic. The sample of analysed companies includes 172 companies in the energy sector from the Czech Republic and 68 companies in the energy sector from the Slovak Republic and 163 companies in the energy sector from Poland. Because of missing data and errors, it was not possible to include Hungary in the research.

To determine the relationship between selected financial indicators and liquidity of companies, medium sized companies, large companies and very large companies were selected. The sample of companies includes combination of public limited company and private limited company.

A medium-sized companies includes less than 250 employees, an annual turnover of less than 50 million EUR or an annual balance sheet total of less than 43 million EUR. A large companies and very large companies can be considered as a companies that exceed the above mentioned criteria for medium-sized companies. The detailed structure of companies in energy sector includes electricity, gas, steam and air conditioning supply such as electric power generation, transmission and distribution, production of electricity, transmission of electricity, distribution of electricity, trade of electricity, manufacture of gas; distribution of gaseous fuels through mains, manufacture of gas, distribution of gaseous fuels through mains, trade of gas through mains, steam and air conditioning supply, steam and air conditioning supply. It is clear from the foregoing that it is an inhomogeneous group which includes entities of a productive nature, of a commercial nature and of a distributional nature. In order to meet the objective of the article, the impact of the structure of sources of financing on the liquidity of V4 enterprises across the industry will be examined. For the purpose of further research, it will be necessary to divide the non-homogeneous group of companies into individual groups according to their manufacturing, commercial and distributional nature and to examine the impact of the structure of sources of financing on the liquidity of V4 enterprises for each group separately.

The dataset cover the period 2006-2015. All data and time series are on annual frequency. The data are the basis for the application of correlation analysis and panel regression analysis, specifically generalized method of moments (GMM).

Correlation analysis and generalized method of moments (GMM) is used to determine the relationship between liquidity of companies and the structure of funding sources. First, we can determine the relationship between liquidity of companies and the structure of funding sources using correlation analysis. The correlation relationship can be expressed using the Pearson correlation coefficient, which may take the following form: 


$$
P=\frac{\Sigma\left(x_{i}-\bar{x}\right)\left(y_{i}-\bar{y}\right)}{(n-1) s_{x} s_{y}}=\frac{\Sigma\left(x_{i}-\bar{x}\right)\left(y_{i}-\bar{y}\right)}{\sqrt{\Sigma\left(x_{i}-\bar{x}\right)^{2} \Sigma\left(y_{i}-\bar{y}\right)^{2}}}
$$

Where $\mathrm{X}$ represents the mean value matrix of liquidity of companies, $\mathrm{Y}$ is the mean of the matrix of the values of the individual variables related to the structure of debt funding sources (explanatory variables) and $\mathrm{n}$ is the number of observations. Pearson's correlation coefficient is based on the calculation by entering the covariance of the variables $\mathrm{X}$ and $\mathrm{Y}$ into the numerator and then by the denominator product of the standard deviations of the variables $X$ and $\mathrm{Y}$, which are defined as the root of the variance of the random variables $\mathrm{X}$ and $\mathrm{Y}$. Covariance describes the degree of mutual variability of the two variables $\mathrm{X}$ and $\mathrm{Y}$. If the variables $\mathrm{X}$ and $\mathrm{Y}$ are in no relation, the covariance is zero.

Pearson's correlation coefficient values range from -1 to 1 , Values close to 1 suggest a positive dependence between the dependent variable and the independent variable, the values approaching -1 have a completely opposite negative relationship. Values approaching 0 show the mutual independence of the variables, where it is not possible to determine unequivocally the dependence between the analyzed variables (there is no linear dependence confirmed here, but it can be a non-linear dependence between the analyzed variables). The variables are uncorrelated in this case. The statistical significance of the correlation coefficient, which can be tested at 1\%,5\% and 10\% significance, plays an important role in determining the relationship between variables.

Correlation and correlation coefficients can be used to determine the relationship between the variables, including the resulting effect, ie whether it is a positive, negative or neutral relationship. However, we are not able to determine how strong the dependence between these variables is, and how is a causal relationship or link between them, when we examine the relationship between the cause and its consequences within the variables analyzed by us.

For this reason, the generalized method of moments (GMM) will be used to determine the impact of the structure of debt funding sources on liquidity of medium-sized companies. The generalized method of moments (GMM) is used in econometrics and statistics. The generalized method of moments (GMM) is a generic method for estimating parameters in statistical models. It is applied in the context of semiparametric models, where the parameter of interest is finite-dimensional, whereas the full shape of the distribution function of the data may not be known, and therefore maximum likelihood estimation is not applicable. The method requires that a certain number of moment conditions were specified for the model. These moment conditions are functions of the model parameters and the data, such that their expectation is zero at the true values of the parameters. The GMM method then minimizes a certain norm of the sample averages of the moment conditions. Hansen (1982) claims that the GMM estimators are known to be consistent, asymptotically normal, and efficient in the class of all estimators that do not use any extra information aside from that contained in the moment conditions.

In order to ensure sufficient reporting ability, all variables will be tested for their statistical significance (for significance levels of $1 \%, 5 \%$ and $10 \%$ ). In addition, the robustness of the model using the Sargan / Hansen J-test, first proposed by John Denis Sargan (1958) and subsequently extended by Lars Peter Hansen (1982), will be verified. The Sargan / Hansen J-test determines to what extent the method is able to provide the same results even when loaded with slight parameter changes. The model is robust in this regard if the results of the Sargan / Hansen test are greater than 0.05. 
In connection with the test, we calculate the value $\mathbf{J}$ from the data when the resulting value is expected in the form of a non-negative number. The resulting $\mathbf{J}$ value is then compared, for example, with 0.95 of the distribution $X_{k-l^{*}}^{2}$ If $I>q_{0,95}^{x_{k-1}^{2}}$, the zero hypothesis $\mathrm{H}_{0}$ is rejected at $95 \%$ confidence. If $I<q_{0,95}^{x_{k-1}^{n}}$, the zero hypothesis $\mathrm{H}_{0}$ can not be rejected at $95 \%$ confidence.

According Haas a Lelyveld (2010), the relationship between liquidity of companies and funding sources will be estimated using the following equations in general form (2):

$$
L_{i t}=\alpha_{1}+\beta_{1} * \Delta L_{i t-1}+\beta_{2} * X_{1 i t}+\beta_{3} * X_{2 i t}+\cdots \ldots+\beta_{n} * X_{\text {nit }}+\varepsilon_{i t}
$$

In consistent with studies Anderson (2002), Mehar (2005), Trippner (2013) and Růčková (2015), variables include debt equity ratio (DER), return on equity (ROE), share of fixed assets to total assets (FA/TA) and return on assets (ROA) and equity ratio (ER)

The dependent variable Lt is an indicator of current liquidity (L3) of companies in the Czech Republic and Slovak Republic at time t, Xnt are other factors that represent funding sources and which may affect the liquidity of companies in the Czech Republic and Slovak Republic. These factors include debt equity ratio (DER), return on equity (ROE), share of fixed assets to total assets (FA/TA), return on assets (ROA), equity ratio (ER). $\beta 0$ and $\varepsilon t$ is model constant and the residual component in the model.

Table 1: Description of used variables

\begin{tabular}{|l|l|c|}
\hline Variables & Calculation & Expected relationship \\
\hline Liquidity (L3) & Current assets/ current liabilities & Dependent variable \\
\hline Debt equity ratio (DER) & Debt/equity & + \\
\hline Return on equity (ROE) & Net profit/ equity & + \\
\hline Fixed assets (FA/TA) & Fixed assets/total assets & $+/-$ \\
\hline $\begin{array}{l}\text { Earnings before interest and taxes } \\
\text { (ROA) }\end{array}$ & $\begin{array}{l}\text { Earnings before interest and taxes/total } \\
\text { assets }\end{array}$ & - \\
\hline Equity ratio (ER) & Equity / total assets & - \\
\hline
\end{tabular}

Source: Authors' calculations

Table no 1 represents description of used variables. The funding sources are represented through the variables (debt equity ratio, return on equity, share of fixed assets to total assets, return on assets, equity ratio). The financial ratios (variables) are used to determine relationship between funding sources and liquidity of companies. The choice of variables and the expected relationship between the variables is based on the above studies.

\section{Results and Discussion}

This part focuses on the results of correlation analysis, generalized method of moments (GMM) and their comments. At first it is necessary to pay attention to the selected structure of funding sources.

First, we can determine the relationship between liquidity of companies and funding sources using correlation analysis. The following table (2) reflects the degree of interdependence of monitored parameters in energy sector in the Czech Republic, the Slovak Republic and Poland. 
Table 2: Correlation between liquidity of companies and selected variables in energy sector in the Czech Republic, in the Slovak Republic and Poland

\begin{tabular}{|l|l|l|l|l|l|}
\hline Current ratio (L3) & DER & ER & ROA & ROE & FA/TA \\
\hline Czech Republic & -0.0074 & $0.3164 *$ & 0.0033 & 0.0028 & -0.0428 \\
\hline Slovak Republic & -0.0247 & $0.2509 *$ & $0.0841 * * *$ & 0.0053 & $-0.1805 *$ \\
\hline Poland & 0.0121 & $0.2753 *$ & $0.0520 * * *$ & -0.0043 & -0.2021 \\
\hline
\end{tabular}

Note: $*$ denotes significance at $1 \%$ level, $* *$ denotes significance at $5 \%$ level, $* * *$ denotes significance at $10 \%$ level

Source: Authors' calculations

The results of the correlation analysis confirm that there is a positive average dependency between the equity ratio and the liquidity of companies in the energy sector in the Czech Republic. This relationship was confirmed at the $1 \%$ level of statistical significance. The rising values of the equity ratio will be accompanied by rising values of the current liquidity ratio (L3).

The results showed a weak positive relationship between the equity ratio and liquidity of companies in the energy sector in the Slovak Republic at $1 \%$ level of statistical significant. Growth of the equity ratio will result in a rise in the liquidity of companies, expressed in terms of the current liquidity ratio (L3). Within the Slovak Republic, the weak dependence between the return on assets and the liquidity of companies at the $10 \%$ level of statistical significance was also felt. Negative weak dependence was demonstrated between the share of fixed assets to total assets and the liquidity of companies in the energy sector in the Slovak Republic. This established relationship was demonstrated at the $1 \%$ significance level.

Table 2 confirms a positive weak dependence at the $1 \%$ level of statistical significance between the equity ratio and the liquidity of companies in the energy sector in Poland. Growth of the equity ratio tends to rise in current liquidity (L3). The results of the correlation coefficients show a slight dependence between the return on assets and the liquidity of companies at the $10 \%$ statistical significance. The links between other financial indicators related to the structure of funding sources were statistically insignificant.

Table 3: Estimation results between liquidity of companies and financial indicators related to the structure of funding sources in energy sector in the Czech Republic

\begin{tabular}{|l|l|l|l|l|}
\hline Variable & Coefficient & Std. Error & t-Statistic & Probability \\
\hline ER & 7.178679 & 1.309279 & 5.482925 & 0.0000 \\
\hline ROA & -1.964857 & 1.055425 & -1.861674 & 0.0630 \\
\hline ROE & 0.013036 & 0.007639 & 1.706541 & 0.0883 \\
\hline FA/TA & -3.204574 & 0.719724 & -4.452505 & 0.0000 \\
\hline
\end{tabular}

Note: $*$ denotes significance at $1 \%$ level, $* *$ denotes significance at $5 \%$ level, $* * *$ denotes significance at $10 \%$ level

Source: Authors' calculations

Table 3 presents the impacts of individual financial indicators related to the structure of funding sources on corporate liquidity in the energy sector in the Czech Republic.

The regression coefficient indicates the change of $\mathrm{Y}$ at the change of the $\mathrm{X}$. If the regression coefficient value is an independently variable positive, it means that the growth of this independent variable will lead to the growth of the dependent variable. Conversely, if the value of the regression coefficient is somewhat negative, it means that the growth of this independent variable will lead to the drop of the dependent variable. 
The standard error of the estimate is a measure of the accuracy of predictions. Standard error is the approximate standard deviation of a statistical sample population. Standard error is a statistical term that measures the accuracy with which a sample represents a population. In the statistics, a sample mean deviates from the actual mean of a population; this deviation is the standard error.

The statistic is a measure of how extreme and statistical estimation is. You calculate this statistic by subtracting the hypothesized value from the statistical estimate and then dividing the estimated standard error. T-statistics are compared with the value of the test criterion at a given significance level $(1 \%, 5 \%$ and 10\%). By comparing t-statistics and test criteria, we reject or accept a zero hypothesis. These conclusions can be obtained by determining the values of the probability coefficient in the table.

Using probability we determine whether the resulting regression coefficients at the significance level of $1 \%, 5 \%$ and $10 \%$ are statistically significant or not. If the resultant probability value is less than $0.01(1 \%), 0.05(5 \%)$ and $0.1(10 \%)$ for the selected regression coefficient, the regression coefficient can be considered statistically significant. If the resultant probability value is greater than $0.01(1 \%), 0.05(5 \%)$ and $0.1(10 \%)$ for the selected regression coefficient, the regression coefficient can be considered statistically insignificant.

Using the generalized method of moments (table 3), it is clear that there is a positive influence of the equity ratio indicator on the liquidity of companies in the energy sector in the Czech Republic. This relationship was demonstrated at the $1 \%$ level of statistical significance. If the equity ratio is increased by one unit, the current liquidity indicator (L3) is also likely to increase by 7.178679 units. The negative impact of return on assets on liquidity of companies was shown at the $10 \%$ level of statistical significance. Return on assets growth will be associated with a decrease in current liquidity (L3). If the return on assets is increased by one unit, the current liquidity indicator (L3) is also likely to decrease by 1.964857 units.

In terms of profitability, the positive effect of return on equity on liquidity of companies was demonstrated at the $10 \%$ level of statistical significance. If the return on equity is increased by one unit, the current liquidity indicator (L3) is also likely to increase by 0.013036 units. If the economic efficiency of businesses increases, this will lead to greater security of their solvency. On the contrary, the negative effect of the indicator of the share of fixed assets to total assets on the liquidity of companies was shown at the $1 \%$ level of statistical significance. If there is a decline in fixed assets, the depreciation value will also decrease, which will encourage normal liquidity. If the indicator of the share of fixed assets to total assets is increased by one unit, the current liquidity indicator (L3) is also likely to decrease by 3.204574 units. All established relationships were tested at a significance level of $1 \%, 5 \%$ and $10 \%$. The results are also in line with the Sargan/Hansen test, which points to the robustness of the resulting model. Table 4 shows the effects of individual financial indicators related to the structure of funding sources on corporate liquidity in the energy sector in the Slovak Republic. 
Table 4: Estimation results between liquidity of companies and financial indicators related to the structure of funding sources in energy sector in the Slovak Republic

\begin{tabular}{|l|l|l|l|l|}
\hline Variable & Coefficient & Std. Error & t-Statistic & Probability \\
\hline ER & 3.020023 & 0.449429 & 6.719691 & 0.0000 \\
\hline ROA & 1.249220 & 0.434477 & 2.875224 & 0.0043 \\
\hline FA/TA & -2.107302 & 0.650677 & -3.238632 & 0.0013 \\
\hline
\end{tabular}

Note: $*$ denotes significance at $1 \%$ level, $* *$ denotes significance at $5 \%$ level, $* * *$ denotes significance at $10 \%$ level

Source: Authors' calculations

It was found that corporate liquidity is affected by the following ratios: equity ratio, return on assets and share of fixed assets to total assets. The positive effect of the equity ratio on the liquidity of companies has been demonstrated to the $1 \%$ level of statistical significance in the Slovak Republic. Growth of the equity ratio raises pressures on corporate liquidity growth, expressed by the current liquidity indicator (L3). If the equity ratio is increased by one unit, the current liquidity indicator (L3) is also likely to increase by 3.020023 units.

A similar effect was demonstrated in the return on assets indicator. There was a positive effect of return on assets on liquidity of companies at the $1 \%$ level of statistical significance. Return on assets growth will lead to a larger volume of liquidity. If the return on assets is increased by one unit, the current liquidity indicator (L3) is also likely to increase by 1.249220 units. Using the generalized method of moments, the negative influence of the share of fixed assets to total assets on corporate liquidity was demonstrated at the $1 \%$ level of statistical significance. Fixed asset growth will lead to an increase in depreciation costs, which will cause a drop in liquidity of companies. If the indicator of the share of fixed assets to total assets is increased by one unit, the current liquidity indicator (L3) is also likely to decrease by 2.107302 units. The Sargan/Hansen test demonstrated the robustness of the model and the above mentioned relationships. Table 5 shows the effects of individual financial indicators related to the structure of funding sources on corporate liquidity in the energy sector in Poland.

Table 5: Estimation results between liquidity of companies and financial indicators related to the structure of funding sources in energy sector in Poland

\begin{tabular}{|l|l|l|l|l|}
\hline Variable & Coefficient & Std. Error & t-Statistic & Probability \\
\hline L3(-1) & -0.342915 & 0.006384 & -53.71326 & 0.0000 \\
\hline DE & 0.000720 & $8.07 \mathrm{E}-05$ & 8.912979 & 0.0000 \\
\hline ER & 4.512277 & 0.546349 & 8.258972 & 0.0000 \\
\hline ROA & -2.780829 & 0.454931 & -6.112635 & 0.0000 \\
\hline FA/TA & -3.948755 & 0.609738 & -6.476148 & 0.0000 \\
\hline
\end{tabular}

Note: $*$ denotes significance at $1 \%$ level, $* *$ denotes significance at $5 \%$ level, $* * *$ denotes significance at $10 \%$ level

Source: Authors' calculations

The resulting values (table 5) show that current liquidity is negatively affected by past current liquidity. If a company records an increase in current liquidity in the previous period, this is reflected in the decrease in the current liquidity ratio in the current period. This relationship was demonstrated at the $1 \%$ level of statistical significance. If the current liquidity indicator in the previous period is increased by one unit, the current liquidity indicator (L3) is also likely to decrease by 0.342915 units. In addition, the positive influence of the debt equity ratio on the liquidity of companies was demonstrated at the $1 \%$ level of statistical significance. Greater use of debt funding will lead to corporate liquidity growth. If the debt equity rattio is increased by one unit, the current liquidity indicator (L3) is also likely to increase by 0.000720 units. On the contrary, the positive impact of the equity ratio indicator on the liquidity of companies has been demonstrated. Growth of equity ratio will lead to corporate 
liquidity growth. If the equity ratio is increased by one unit, the current liquidity indicator (L3) is also likely to increase by 4.512277 units.

The results of the GMM method have shown that return on assets and the share of fixed assets to total assets negatively affect the liquidity of companies in the energy sector. Growth of return on assets and the share of fixed assets to total assets decrease in liquidity of companies. If the return on assets is increased by one unit, the current liquidity indicator (L3) is also likely to decrease by 2.780829 units. If the indicator of the share of fixed assets to total assets is increased by one unit, the current liquidity indicator (L3) is also likely to decrease by 3.948755 units. All resulting relationships were demonstrated at a $1 \%$ significance level. Based on the Sargan/Hansen test, the robustness of the model was confirmed.

\section{Conclusion}

The aim of this paper was to determine the effect of structure of funding sources on liquidity of companies in energy sector in the Visegrad group from 2006 to 2015. With the purpose to fulfill the aim, we examined existence and character of relationship between structure of funding sources (debt equity ratio, equity ratio, return on equity, return on assets and fixed assets to total assets) and liquidity of the companies in energy sector in Visegrad group including the Czech Republic, the Slovak Republic and Poland. The existence of relationship between structure of funding sources and liquidity of companies was tested by correlation analysis and generalized method of moments (GMM).

For all analyzed countries, the positive effect of the equity ratio on the liquidity of companies in the energy sector was demonstrated. If the equity ratio is increased by one unit, the current liquidity indicator (L3) is also likely to increase by 7.178679 units in the Czech Republic. If the equity ratio is increased by one unit, the current liquidity indicator (L3) is also likely to increase by 3.020023 units in the Slovak Republic. If the equity ratio is increased by one unit, the current liquidity indicator (L3) is also likely to increase by 4.512277 units in Poland. If there is a growth in own funding sources, corporate liquidity will be ensured. This is not consistent with the theoretical bases, which have a negative relationship between equity ratios and liquidity of companies. Own funding sources include profits from past years. In line with this, the positive impact of return on equity on corporate liquidity in the Czech Republic was demonstrated.It means that if the return on equity is increased by one unit, the current liquidity indicator (L3) is also likely to increase by 0.013036 units. Return on equity growth will lead to an increase in the liquidity of companies. More profitable businesses are much more able to finance their own business from their own resources, pay dividends and create reserves in the form of liquidity. It should be noted that compared to other results, the results of the GMM method showed a weak impact of the return on equity on corporate liquidity. The value of the regression coefficient (0.013036) is very low compared to other results. The profitability results identified correspond to the results found in the Slovak Republic, where the positive effect of return on assets on corporate liquidity has been demonstrated. It means that if the return on assets is increased by one unit, the current liquidity indicator (L3) is also likely to increase by 1.249220 units. If a firms reaches a higher return on assets, there will be a rise in liquidity of companies. These results confirm the study of Trippner (2013), which found positive relation between corporate liquidity and return on assets. More profitable companies are those that can use their retained earnings to finance their investment projects. We can argue that the more liquid the firm is, it is the less leveraged.

The negative impact of return on assets on liquidity of companies has been demonstrated within the Czech Republic and Poland. If the return on assets is increased by one unit, the 
current liquidity indicator (L3) is also likely to increase by 1.249220 units in the Czech Republic. If the return on assets is increased by one unit, the current liquidity indicator (L3) is also likely to decrease by 2.780829 units in Poland. This resulting relationship can be justified by the statement that the growth of profitability is accompanied by declining corporate liquidity values. Funds may be invested by the enterprise in more profitable projects compared to cash that yields a minimum return or no return. These results confirm study of Trippner (2013), which also found negative relationship between corporate liquidity and return on assets. The results of Tripnner (2013) demonstrated both the positive link between liquidity and ROA and ROE, as well as the negative link between liquidity and ROA and ROE.

In addition to own funding sources, an enterprise may use debt funding sources to finance its business activities. The positive impact of the debt equity ratio on the liquidity of companies in Poland was demonstrated in relation to debt funding sources. It menas that if the debt equity rattio is increased by one unit, the current liquidity indicator (L3) is also likely to increase by 0.000720 units. Growth of the debt equity ratio will lead to a rise in current liquidity. Money transfers through loans can be invested by the enterprise in profitable projects, thereby under-pinning profitability by which an enterprise can create financial cushions in case of un-expected events. In the other analyzed countries, no clear relationship was established. These results are consistent with Milos (2015) who found a negative connection between liquidity and leverage.

In all analyzed countries, the share of fixed assets to total assets on liquidity of companies was negatively affected. It means that if the indicator of the share of fixed assets to total assets is increased by one unit, the current liquidity indicator (L3) is also likely to decrease by 3.204574 units in the Czech Republic. If the indicator of the share of fixed assets to total assets is increased by one unit, the current liquidity indicator (L3) is also likely to decrease by 2.107302 units in the Slovak Republic. If the indicator of the share of fixed assets to total assets is increased by one unit, the current liquidity indicator (L3) is also likely to decrease by 3.948755 units in Poland. The decline in fixed assets will lead to a decline in depreciation costs, which is considered as a source of funding. The decrease in depreciation costs will lead to the growth of corporate liquidity.

To summarize the results achieved, it can be stated that the positive impact of the debt equity ratio on the liquidity of companies in the Visegrad Group has been demonstrated. On the contrary, the positive and negative impact of the financial ratios related to the structure of own funding sources on the corporate liquidity in the Visegrad Group was demonstrated. These results open up many further questions for further research where it would be appropriate to examine the impact of financial indicators related to the structure of funding sources on corporate liquidity within individual sectors or the size of companies. Similarly, there is area for using other dependent variables to represent the solvency of the business.

\section{Acknowledgement}

This paper ensued thanks to the support of the grant SGS/7/2018 "Analysis of the influence of selected aspects on the financial structure of companies in the conditions of Central and Eastern European countries“". 


\section{References}

[1] ANDERSON, R. W., 2002. Capital structure, firm liquidity and growth. Working papers research series. National Bank of Belgium. [online] [vid. 01-02-2017]. Available from:: www.nbb.be/doc/ts/publications/wp/WP27en.pdf.

[2] DE JONG, A., R. KABIR and T. T. NGUYEN, 2008. Capital structure around the world: the roles of firm and country specific determinants. Journal of Banking and Finance, 32, 1954-1969.

[3] FRANCESCO, F., E. NOWAK and L. PHALIPPOU, 2011. Private Equity Performance and Liquidity Risk. Journal of Finance, Forthcoming; Swiss Finance Institute Research Paper No. 09-43. Available at SSRN: https://ssrn.com/abstract=1517044 or http://dx.doi.org/10.2139/ssrn.1517044

[4] GANESAN, V., 2007. An Analysis Of Working Capital Management Efficiency In Telecommunication Equipment Industry. Rivier Academic Journal, 3(2). ISSN 15599388 .

[1] GHASEMI, M. and N. H. AB RAZAK, 2016. The Impact of Liquidity on the Capital Structure: Evidence from Malaysia. International Journal of Economics and Finance, 8(10), 130. ISSN 1916-9728.

[5] HAAS, R. and I. LELYVELD, 2010. Internal capital markets and lending by multinational bank subsidiaries. Journal of Financial Intermediation [online]. 19, 1-25 [vid. 2017-03-01]. Available from: www.sciencedirect.com/science/article/B6WJD4VJ07JK1/2/49949562160fbe5ed0a1dae3c3f1ee93

[6] HANSEN, L. P., 1982. Large Sample Properties of Generalized Method of Moments Estimators. Econometrica, 50(4), 1029-1054. ISSN 1468-0262.

[7] LIPSON, M. L. and S. MORTAL, 2009. Liquidity and capital structure. Journal of Financial Markets. 12(4), 611-644. ISSN 1386-4181.

[8] MEHAR, A., 2005. Impacts of equity financing on liquidity position of a firm. Applied Financial Economics, Vol. 15, 425-438. ISSN 1466-4305.

[9] MILOŞ, M. C., 2015. Capital Structure Determinants. Evidence from the Romanian Listed Companies. Analele Universitatii 'Eftimie Murgu' Resita. Fascicola II. Studii Economice, 129-134. ISSN 2344-6315.

[10] RƯČKOVÁ, P., 2015. Impact of Liquidity and Profitability on Use of Debt Finance Sources of Companies in Manufacturing Industry in V4 Countries. Acta academica Karviniensia, 15(3), 69-79. ISSN 1212-415X.

[11] SHAH, P., 2012. Evaluation of Profitability and Liquidity Relationship through Multivari-ate Working Capital Analysis. A Management Journal, 3(2), 177. ISSN 23485302.

[12] SCHLEIFER, A. and R. W. VISHNY, 1992. Liquidation Values and Debt Capacity: A Market Equilibrium Approach. Journal of Financial Economics [online]. [vid. 1. února 2017]. Available from: http://onlinelibrary.wiley.com/doi/10.1111/j.15406261.1992.tb04661.x/full

[13] SIBILKOV, V., 2007. Asset liquidity and capital structure [online]. [vid. 2017-05-23] Available from: panther-file.uwm.edu/sibilkov/www/liquidity.pdf

[14] STULZ, R., 1990. Managerial discretion and optimal financing policies. Journal of financial Economics, 26(1), 3-27. ISSN 0304-405X 
[15] ŠARLIJA, N. and M. HARC, 2012. The impact of liquidity on the capital structure: a case study of Croatian firms. Business Systems Research, 3(1), 30-36.

[16] TITMAN, S. and R. WESSELS, 1988. The determinants of capital structure choice. The Journal of Finance, 43(1), 1-19. ISSN 1540-6261.

[17] TRIPPNER, P., 2013. Analysis of Financial Liquidity Management in the Enterprise and its Impact on the Profitability. In: STAVÁREK, D. a P. VODOVÁ (ed). In: Proceedings of 14th International Conference on Finance and Banking. Karviná: Silesian University, School of Business Administration, s. 494-501. ISBN 978-80-7248-939-8.

[18] WILLIAMSON, O. E., 1988. Corporate Finance and Corporate Governance. Journal of Finance, 43(3), 567-591. ISSN 1540-6261. 